\title{
Protein quality of feeding-stuffs
}

\section{4.* Progress report on collaborative studies on the microbiological assay of available amino acids}

\author{
BY A. W. BOYNE \\ Rowett Research Institute, Bucksburn, Aberdeen
}

S. A. PRICE

Walton Oaks Experimental Station, Vitamins Ltd, Tadworth, Surrey

G. D. ROSEN

Field Investigations and Nutrition Services Ltd, 3 I 0 Regent Street, London, $W$ I

AND J. A. STOT'T

F. Bibby and Sons Ltd, King Edward Street, Liverpool 3, Lancs.

(On behalf of the Microbiological Panel of the Agricultural Research

Council Group on Tests of Protein Quality)

$$
\text { (Received } 30 \text { fune 1966-Accepted I2 October 1966) }
$$

\footnotetext{
1. Samples of whale, meat, fish, groundnut and soya-bean meals and skim-milk powders were assayed microbiologically with Tetrahymena pyriformis W and Streptococcus zymogenes for available methionine and available lysine.

2. Detailed collaborative studies on the assay of available methionine with Strep. zymogenes were conducted on the effects of dry- or wet-grinding the test meals, the use of crude or purified papain for predigesting the ground meals and the use of optical density or titratable acidity as criteria of bacterial growth response.

3. Wide differences were observed in the available methionine and available lysine contents of a variety of meals in the preliminary studies, with a promising measure of interlaboratory agreement in the assay of available methionine with Strep. zymogenes.

4. As a result of detailed collaborative studies a provisional method is proposed for the assay of available methione with Strep. zymogenes, adopting dry-grinding and predigestion with an agreed level of papain in the preparation of the meals. No general recommendation could be offered on the comparative merits of optical density and titratable acidity as criteria of bacterial growth response.
}

The following workers also collaborated in the work described in this paper:

D. E. Waterworth, J. Bibby and Sons Ltd, Nutrition Research and Advisory Department, 'Weatherstones', Neston, Wirral, Cheshire.

A. E. Bender, Farley's Infant Food Ltd, Galleymead Road, Colnbrook, Slough, Bucks.

J. E. Ford and K. J. Scotr, National Institute for Research in Dairying, Shinfield, Reading, Berks.

L. D. WARD, Spillers Ltd, Central Laboratories, Station Road, Cambridge.

* Paper no. 3: Br. F. Nutr. (1964), 18, 545. 
E. L. Miller and Clare B. Morgan, School of Agriculture, University of Cambridge, Cambridge.

L. Gare, Walton Oaks Experimental Station, Vitamins Ltd, Tadworth, Surrey.

The formation by the Agricultural Research Council, in 1955, of a Protein Quality Group to undertake collaborative work on the development of laboratory procedures for the assessment of protein quality in animal feeding-stuffs was reported by Zuckerman (1959). Boyne, Carpenter \& Woodham (I96I) gave a comprehensive progress report on the work of the group to 1960 on r 30 samples of seven types of protein concentrate in thirteen participating laboratories and they compared the results of various chemical and microbiological procedures with gross protein values (GPV) for chicks and net protein utilizations (NPU) and net protein ratios (NPR) for rats. Useful correlations were found between protein qualities for rats and chicks and those for Tetrahymena pyriformis W, Streptococcus zymogenes and Streptococcus faecalis, notably in the meat and whale meal series. Bunyan \& Woodham (1964) and Barber, Braude, Chamberlain, Hosking \& Mitchell (r964) later reported detailed chemical and biological tests on three selected fish meals; the tests included nutritive values and available lysine and methionine contents determined with $T$. pyriformis $\mathrm{W}$ and Strep. zymogenes.

By 1959 it was apparent to the Group from many of the aforementioned, then unpublished, results and from reports in the literature, which was reviewed by Rosen (1959), that microbiological methods have a considerable potential for the evaluation of protein quality. These methods offered possibilities of greater economy in time, money, labour and materials as compared with feeding tests on laboratory and farm animals and they seemed also to be particularly relevant to the screening of large numbers of samples for protein quality by their relatively rapid 2- to 4-day test period procedures. Microbiological assays on intact proteins are noteworthy for their ability to reflect differences of biological availability not necessarily revealed by conventional ion exchange chromatographic analysis or microbiological assay of the individual total amino acid contents of protein foodstuffs, following their complete chemical hydrolysis.

These considerations led the Group in 1959 to form a Microbiological Panel of specialists in the field of microbiological assay to consider and, if necessary, to develop possible microbiological methods that could be applied for the selection of animal feeds for protein quality. Part of the Panel's programme would be to assess the procedures on a collaborative basis.

At the time of formation of the Panel the literature on the application of microbiological assay to the assessment of protein quality encompassed methods based on three different principles as follows:

(a) Determination of the amounts of individual amino acids in hydrolysates prepared by acid, alkaline, or more rarely, enzymic digestion. Several different species of micro-organisms have been used for this purpose, but most workers have preferred lactic acid bacteria, already familiar and widely employed in vitamin assays (see e.g. Barton-Wright, r963; Shockman, 1963). When chemical hydrolysis is used, this 
approach fails to reveal important differences in digestibility and amino acid availability; the failure is especially marked with heat-processed protein materials used for animal feeding.

(b) Measurement of the nutritive quality, for micro-organisms, of the mixture of amino acids and peptides released by in vitro enzymic digestion of the test protein using, for example, Leuconostoc mesenteroides or Strep. faecalis. This approach attempts thus to take into account digestibility and the amino acid composition and has been used by Halevy \& Grossowicz (1953), Horn, Blum \& Womack (1954) and Teeri, Virchow \& Loughlin (1956), who have reported a few results in fair agreement with animal tests. Bunyan \& Price (I960) found that Strep. faecalis assays of enzymic digests of whale meals gave results correlating closely with those of rat feeding tests. Rogers \& McLaughlan (1958) and Rogers, McLaughlan \& Chapman (I959), however reported lack of agreement, due to autolysis, using Strep. faecalis in hydrolysates deficient in lysine. They considered that these methods were only valid when standard and sample were limited by the same amino acid; they concluded that the methods were unsatisfactory for screening foods.

(c) Nutritive evaluation of proteins using proteolytic protozoa and bacteria. Dunn \& Rockland (1947) attempted to use the protozoan Tetrahymena geleii $\mathrm{H}$ for three purified proteins, but their assay lasted 4I days. Pilcher \& Williams (1954) tested three foodstuffs with $T$. pyriformis $\mathrm{W}$ but found substantial differences in the relative nutritive values of egg and groundnut protein between $3^{-}$and $5_{\text {-day assays, due }}$ probably to their use of a dye reduction response to estimate growth, which was later demonstrated to be unsatisfactory by Fernell \& Rosen (1956). Fernell \& Rosen (1954, 1956) and Rosen \& Fernell (1954, 1956) developed and used T. pyriformis W for the 4-day assay of intact proteins in a wide range of twenty vegetable and animal foodstuffs and established by comparison with the results of rat assays the value of microbiological assays as an adjunct to feeding trials. Rosen (I959) reported a successful simplification of the $T$. pyriformis assay, its application to cereals, and proposed as a result its use for the microbiological assay of individual amino acid availabilities in proteins. The use of the same organism for measurement of the protein quality of compound (mixed) animal feeds (Rosen, Stott \& Smith, I960a, $b$ ) was a valuable extension of its practical applications. T. pyriformis $\mathrm{W}$ requires absolutely: arginine, histidine, isoleucine, leucine, lysine, methionine, phenylalanine, threonine, tryptophan and valine, the ten amino acids generally regarded as essential for the growth of higher animals.

A bacterial method for measuring protein digestibility was recommended by Mertz, Rennert \& Cole (1955) employing the strongly proteolytic Pseudomonas aeruginosa; the results were in general agreement with those found in tests with rats.

In r959, Ford (private communication to the Panel) drew attention to the use of the proteolytic bacterium, Strep. zymogenes, for protein assays (Ford, r 960). This organism appeared to offer advantages of simplicity of assessment of growth response and a shorter, 2-day, assay period when speeded up by predigestion of the proteins with papain. Strep. zymogenes has absolute requirements for only eight amino acids, seven of them essential for animals-arginine, histidine, isoleucine, leucine, methionine, 
tryptophan and valine-plus glutamic acid; lysine and serine, though not essential, were reported to be stimulatory (Ford, I960).

The Panel's exploratory studies led it to conclude that microbiological tests of overall nutritive value (protein quality) could have their usefulness as grading tests as they are well capable of distinguishing 'good' from 'poor' samples of the same type of material. Although in certain situations such grading tests can be of value, they are as yet, like the determination of NPU and GPV in animals, of limited help to the feedingstuffs manufacturer, who may wish to know the values of a high-protein supplement as a source of specific amino acids.

The aim of the manufacturer of compound feeding-stuffs is to produce better balanced mixed feeds, adequate for the species for which they are intended, not only in protein, energy, vitamins and minerals, but also in essential amino acids. In the literature and in the many tabulated compilations available, however, he finds that there are considerable differences between the 'average' total amino acid contents quoted by different authorities for the various types of designated feeding-stuffs and also that the range of values, from which each of these averages is computed, contains a very considerable sample-to-sample variation. Furthermore, these chemically determined values cannot take into account the digestibility or the biological availability of the individual amino acids, which in heated protein foods may be appreciably less than the 'total' values suggest. This concept of amino acid availability has been given more attention in recent years, especially in relation to the 'binding' of lysine in heat-damaged proteins, for which the dinitrofluorobenzene (DNFB) test (Carpenter, I960) for 'available' lysine value (ALV) is becoming widely used. No corresponding chemical method of analysis has been proposed for the availability of other essential amino acids, such as methionine, which is commonly held to be limiting in compound feeds. The Panel therefore decided in 1961 to concentrate its attention on the measurement of available amino acids, such as methionine and lysine, and in particular the former, for which at the time no accepted biological or convenient chemical test existed.

The work described in this paper was conducted under the auspices of the Microbiological Panel from 1959 to 1964 . It may be noted that the individual laboratories participating were simultaneously engaged in the development and improvement of methods under collaborative study by the Panel, and some detailed accounts of these have been published (Ford, 1962, 1964; Miller, Carpenter \& Morgan, 1963; Miller, Carpenter, Morgan \& Boyne, 1965; Rosen, Stott \& Smith, I962; Stott, Smith \& Rosen, I963; Stott \& Smith, I966; Waterworth, I964).

This progress report on the Panel's collaborative work deals briefly with some exploratory studies and in more detail with three preliminary studies (nos. I-3) on the measurement of the microbiological availability of lysine and methionine in a range of meals, and also with two more detailed studies (nos. 4 and 5) on certain aspects of the assay of available methionine in protein concentrates. The scope of these studies is summarized in Table $\mathbf{I}$. 
Table I. Summary of the individual studies, types and numbers of meals used, assay organism and number of participating laboratories

\begin{tabular}{|c|c|c|c|c|c|}
\hline $\begin{array}{l}\text { Study } \\
\text { no. }\end{array}$ & Subject & Meals used & Organism & $\begin{array}{l}\text { No. of } \\
\text { labora- } \\
\text { tories }\end{array}$ & $\begin{array}{c}\text { Results } \\
\text { Table } \\
\text { no. }\end{array}$ \\
\hline I & $\begin{array}{l}\text { Total and available } \\
\text { methionine }\end{array}$ & $\begin{array}{l}\text { Whale (I } 2) \text {, meat (I 1), } \\
\text { soya-bean (6), } \\
\text { groundnut (5) }\end{array}$ & $\begin{array}{l}\text { Strep. zymogenes } \\
\text { T. pyriformis } \mathrm{W}\end{array}$ & $\begin{array}{l}5 \\
I\end{array}$ & $\begin{array}{l}2 \\
2\end{array}$ \\
\hline 2 & $\begin{array}{l}\text { Available lysine and } \\
\text { available methionine }\end{array}$ & Fish (3) & $\begin{array}{l}\text { Strep. zymogenes } \\
\text { T. pyriformis } \mathrm{W}\end{array}$ & $\begin{array}{l}3 \\
1\end{array}$ & $\begin{array}{l}3 \\
3\end{array}$ \\
\hline 3 & $\begin{array}{l}\text { Effect of sample } \\
\text { preparation on } \\
\text { available lysine and } \\
\text { available methionine }\end{array}$ & $\begin{array}{l}\text { Soya-bean }(2), \\
\text { groundnut }(2), \\
\text { meat }(2) \text {, whale (2) }\end{array}$ & T. pyriformis W & I & 4 \\
\hline \multirow[t]{2}{*}{4} & $\begin{array}{l}\text { Effect of sample pre- } \\
\text { paration, prediges- } \\
\text { tion and growth } \\
\text { response criteria on } \\
\text { available methionine }\end{array}$ & $\begin{array}{l}\text { (a) Soya-bean (2), } \\
\text { groundnut (2), } \\
\text { fish (I), whale (I) }\end{array}$ & Strep. zymogenes & 3 & 5 \\
\hline & & $\begin{array}{l}\text { (b) Whale (2), meat } \\
\text { (2), fish (I) }\end{array}$ & Strep. zymogenes & 4 & 5 \\
\hline 5 & $\begin{array}{l}\text { Effect of sample } \\
\text { preparation and } \\
\text { growth response } \\
\text { criteria on available } \\
\text { methionine }\end{array}$ & $\begin{array}{l}\text { Fish }(4), \text { skim-milk } \\
\text { powder }(3), \text { soya- } \\
\text { bean }(4), \text { meat (I), } \\
\text { groundnut (I) }\end{array}$ & Strep. zymogenes & 5 & 6 \\
\hline
\end{tabular}

* In study 5 available methionine content was also measured in one laboratory with T. pyriformis W but the preparatory and response variables were not included.

\section{EXPERIMENTAL METHODS}

\section{Protein meals}

Almost all of the samples tested were from those collected by the Agricultural Research Council Group on Protein Quality (Zuckerman, 1959) for collaborative work on the protein quality of meals representative of a variety of sources and types in the commercial market. The samples are identified by their serial number and conventional code initials according to the type of meal, namely, fish meals-FM, whale meals-WM, meat meals-MM, skim-milk powders-SM, groundnut meals-GN and soya-bean meals-SB.

In addition, a control sample of freeze-dried cod muscle meal ( $\mathrm{C} 23$ ) made from cod fillet (Miller, Carpenter \& Milner, 1965) was used in study 4. For the exploratory studies each laboratory selected its own samples and for studies I, 3, 4 and 5 they were selected by the Panel to cover an acceptable range of types and qualities.

For study I milled samples of the meals were circulated to the participants and, in order that estimates of percentage availability could be made, the collaborators using Strep. zymogenes agreed also to measure total methionine on hydrolysates made in one of the laboratories. Similar trials were also made on a series of eleven meat meals, a series of six soya-bean meals and a series of five groundnut meals. For these, however, 
each laboratory prepared its own acid hydrolysate for the total methionine assay. In study 2 the three fish meals were those used by Bunyan \& Woodham (1964) and Barber et al. (1964).

\section{Microbiological assays}

Assay of available methionine with Streptococcus zymogenes. The method originally used was that of Ford (1962). It was modified in the course of the Panel's work, notably to include the increased level of enzyme for predigestion used by Miller et al. (1963) and Miller, Carpenter, Morgan \& Boyne (1965). The provisional method adopted is given in Appendix A, the response being measured turbidimetrically unless otherwise stated. The variants of the method adopted in studies $1,2,4$ and 5 were:

In study I the enzyme predigestion was carried out on dry-ground samples that had passed a $60-m e s h$ sieve containing roo $\mathrm{mg} \mathrm{N}$; I ml of I \% (w/v) crude papain (British Drug Houses Ltd, Poole, Dorset) and $20 \mathrm{ml}$ of citrate-cyanide buffer (see Appendix A) were used.

In study 2 the papain concentration was increased to $2 \mathrm{ml}$ of $4 \%$ and the pepsin pretreatment involved the use of a $1 \%$ (w/v) solution of crystalline pepsin (British Drug Houses, Ltd) in N/30 HCl. Wet-grinding ('homogenizing') was carried out, in the apparatus described by Ford (1964), on the sample that had passed through 40mesh sieve and which contained precisely $100 \mathrm{mg} \mathrm{N}$. When papain was to be used there was added to the sample $15 \mathrm{ml}$ of citrate-cyanide buffer, and after grinding the sample was transferred to a wide-necked $\mathrm{r}$ oz screw-capped bottle with an additional $5 \mathrm{ml}$ of citrate buffer used for rinsing the 'homogenizer' tube and pestle, and adjusted to $\mathrm{pH} 7 \cdot 2$ in readiness for digestion by papain. Alternatively, when pepsin was to be used, the sample was wet-ground with $20 \mathrm{ml}$ of $0 . \mathrm{I} \mathrm{N}-\mathrm{HCl}$, transferred to a screw-capped bottle by rinsing with an additional two $5 \mathrm{ml}$ portions of the acid and adjusted to $\mathrm{pH}$ r 8 .

In study 4 the three preparation treatments of the samples were:

(a) Ground dry through 40-mesh and predigested with I $\mathrm{ml}$ of $\mathrm{I} \%$ (w/v) purified papain (L. Light and Co. Ltd, Colnbrook), assayed (in Laboratory E by Anson's (1938-9) method and in Laboratory D by the agar diffusion method of Carter \& Sykes ( $(96 \mathrm{I})$ ) at $4 \cdot 2$ times the activity of the crude papain used in studies $I$ and 2.

(b) Ground dry through 40-mesh and predigested with I $\mathrm{ml}$ of I\% (w/v) crude papain (unspecified laboratory samples).

(c) As (b), but ground wet as in study 2 .

In study 5 the provisional method described in Appendix A was employed for dryground samples and the wet-grinding was as in study 2 .

Total methionine assays. In study $\mathbf{I}$ the assay of total methionine content was effected by the use of Strep. zymogenes with chemical hydrolysates of various meals instead of the enzyme hydrolysate in the method for available methionine. Portions of hydrolysates of the whale meals for distribution to all participants were prepared in one laboratory by heating samples containing $100 \mathrm{mg} \mathrm{N}$ with $4^{\circ} \mathrm{ml}$ of $2 \mathrm{~N}-\mathrm{HCl}$ for $5 \mathrm{~h}$ at $115^{\circ}$ in sealed tubes; for the meat, soya-bean and groundnut meals each laboratory prepared its own hydrolysate. 
Assay of available lysine and methionine with Tetrahymena pyriformis $W$. The general assay technique was that of Stott et al. (1963) for the nutritive value of proteins; the exact procedure for assay of available amino acids in studies 1,2 and 3 (Stott \& Smith, 1966) is given in Appendix B.

\section{RESULTS \\ Exploratory studies}

For the first 2 years, members of the Panel were completing the assays of nutritive value reported later by Boyne et al. ( $196 \mathrm{r}$ ) and also extending the range of their testing of meat, whale and fish meals, milk powders and cottonseed, groundnut and soyabean meals. Simultaneously they were pursuing their own particular lines of investigation but generally using as far as practicable the same selection of samples from the wide range available. The materials tested were graded according to the overall nutritive value of their protein. One laboratory was measuring the relative nutritive values of enzymic digests for Strep. faecalis (Bunyan \& Price, 1960), one was determining the absolute nutritive values for $T$. pyriformis W (Stott et al. 1963) and the other two were studying the relative nutritive values for Strep. zymogenes (Ford, 1960).

From these studies it was evident (see Boyne et al. 196r) that, over a wide range of animal protein samples, there were highly significant correlations between the microbiological and biological assessments, especially GPV for chicks.

Exploratory attempts were also made to determine which amino acids were limiting in tests of relative nutritive value. For Strep. zymogenes, the culture media were supplemented either with each amino acid singly or with a mixture of seven to ten essential amino acids from which each in turn had been omitted. There were many samples for which one supplementary amino acid alone gave either no response or only a very small increase in growth, possibly owing to the deficiency of the second limiting amino acid being almost as great as that of the primary limiting amino acid. Tests in which mixed amino acid supplements were used gave inconclusive results. In general, for Strep. zymogenes, isoleucine, leucine and valine appeared to be the amino acids most commonly limiting in the fish meal samples examined, and methionine, either alone or with other amino acids such as arginine and isoleucine, frequently appeared to be a limiting factor in the meat meals.

With $T$. pyriformis $\mathrm{W}$ tests were conducted by the addition of single essential amino acids. For this organism the meat meals were commonly limited by either lysine or methionine or by both, the fish meals and soya-bean meals by methionine and the groundnut meals by lysine, but for the whale meals no clear limitation was detected.

\section{Studies I-3. Preliminary collaborative studies on the assay of available methionine and lysine}

These studies were made with both $T$. pyriformis (one laboratory only) and Strep. zymogenes (five laboratories).

The results of study $I$ are summarized in Table 2. Quite good interlaboratory agreement was obtained in the Strep. zymogenes assays of the whale meal series, 
especially for the estimates of total methionine, with the exception of one laboratory, which had no previous experience with the assay technique and obtained low results; results from that laboratory were excluded from the means and ranges. This exception was no longer apparent in the other series of meals, which were assayed some months later. The meat meals, however, gave results generally less reproducible between

Table 2. Study I. Preliminary assays of total and available methionine $(\mathrm{g} / \mathrm{r} 6 \mathrm{~g} N)$ in whale, meat, soya-bean and groundnut meals. Results are mean values, and ranges from participating laboratories

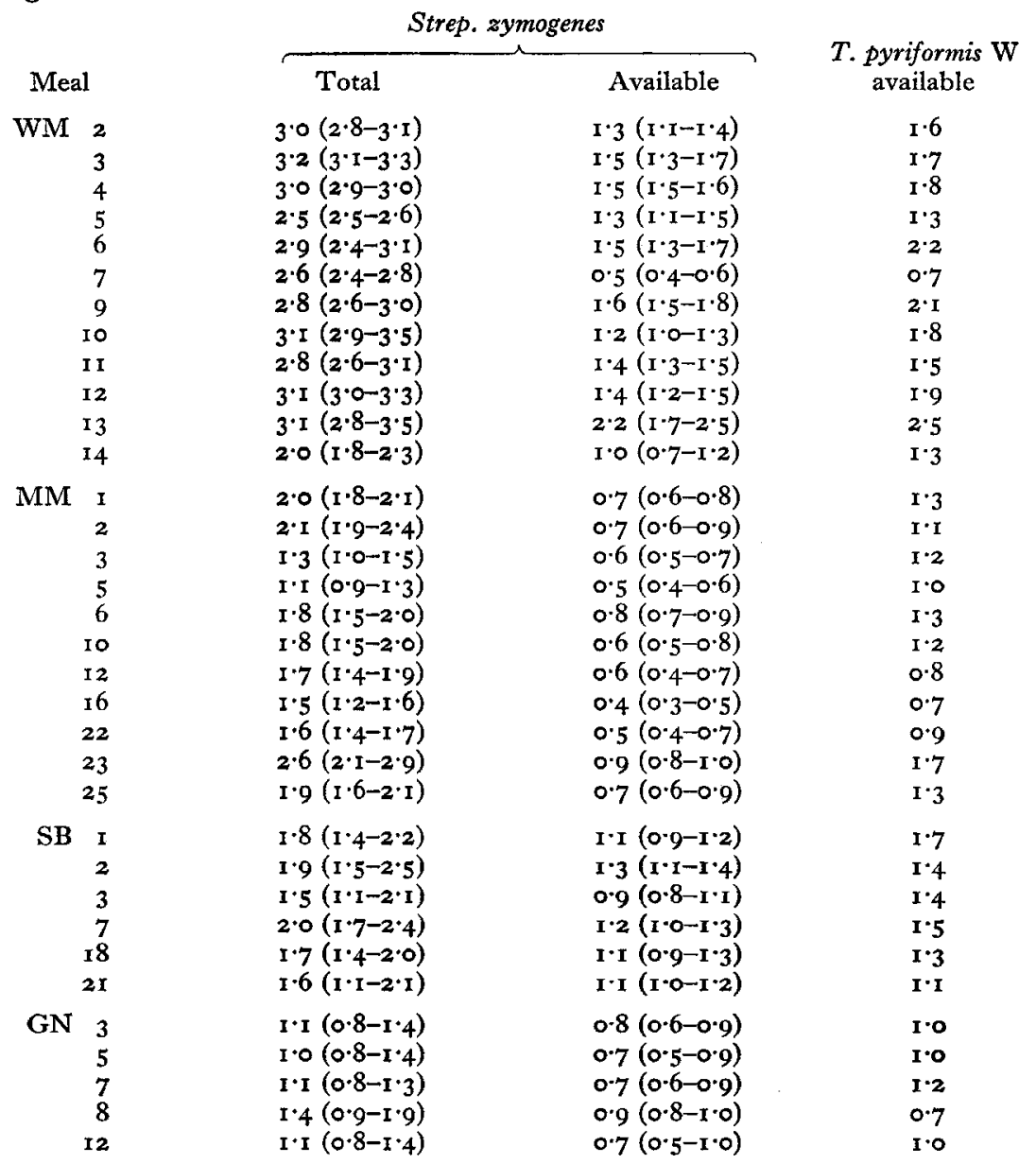

Strep. zymogenes: Whale meals, results from four laboratories; other meals, results from five laboratories.

T. pyriformis W: Results from one laboratory only.

laboratories than were found with the whale meals, possibly because the test samples were more difficult to mill and produced highly turbid extracts. The vegetable meals similarly proved more difficult to work with for Strep. zymogenes assays.

The available methionine values for $T$. pyriformis $\mathrm{W}$ were generally higher than the corresponding average Strep. zymogenes values for whale, soya-bean and groundnut 
Vol. 2I

노ำ

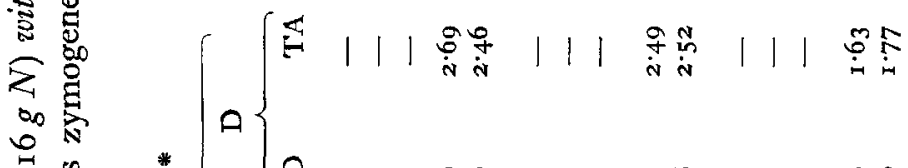

$\frac{1}{30}$

路

今े

ङ

胥莡

₹

$\sum b_{b}^{\infty}$

$x_{0} \frac{1}{x_{0}}$

$\frac{1}{30}$

$\therefore \cdot \frac{1}{2}$

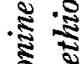

竞

ฐँ

:

है के

की

स है

니

क

\& 8

$\approx 8$

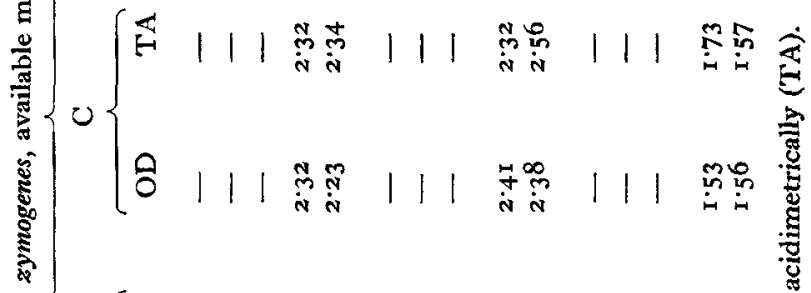

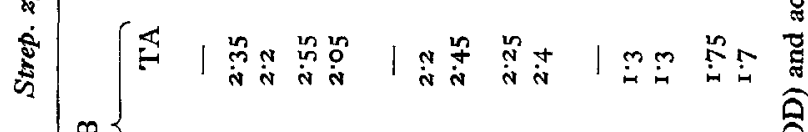

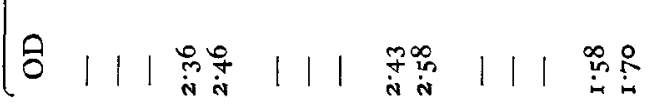

है

今

O |

हो จे

. 5

:

$\therefore$

.

帘

ㄴ.

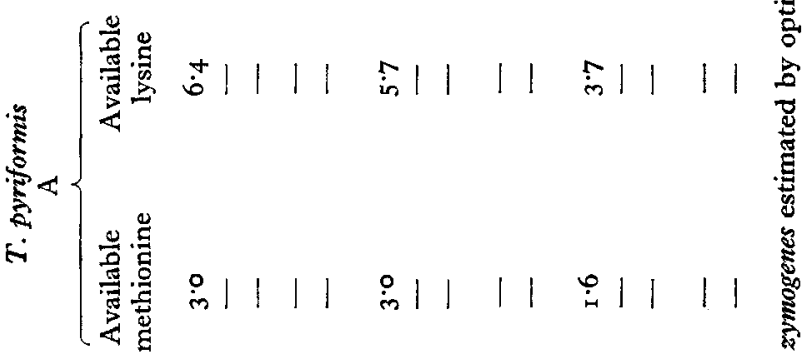

ฐี

उत्

的

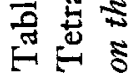

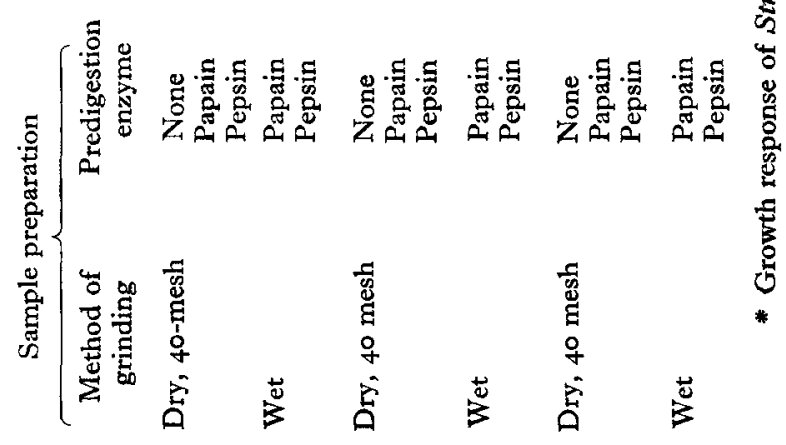

$\sum_{i}^{\mathbb{2}} \sum_{i}^{+}$

$\sum_{\substack{n \\ \text { N }}}^{n}$

$\sum_{1}^{\infty}$ 
meals, and considerably so for the meat meals, notwithanding the enzymic predigestion of the test protein employed with the latter organism.

During the course of the Panel's work, arrangements were made by the Protein Quality Group Biological Panel to assess the protein quality of three specially selected fish meals, FM 24, FM 25 and FM 26, for growing/fattening pigs as well as rats and chicks. In study 2, three laboratories using Strep. zymogenes and one laboratory using $T$. pyriformis $\mathrm{W}$ determined available lysine and available methionine values of these three meals, with results given in Table 3 . Some of these results have previously been reported in order to compare them with those obtained with animals (Barber et al. r964; Bunyan \& Woodham, I964). With both micro-organisms FMI 26 appeared to be substantially lower in available methionine than FM 24 and FM 25. Available lysine measurements by Tetrahymena gave the same differentiation. No consistent difference in assessment for these three meals was given by the variations in sample preparation or the response criteria used.

In study 3 a small-scale comparison on eight meals of four types (two each of whale, meat, soya-bean and groundnut) was made of the contents of lysine available to $T$. pyriformis W for dry- and wet-ground preparations. The results are given in Table 4 in comparison with available methionine contents of the samples measured by the standard dry-ground method used routinely for this organism. Wet-grinding did not increase the available lysine measured by $T$. pyriformis W.

Table 4. Study 3. Available lysine $(\mathrm{g} / \mathrm{r6} \mathrm{g} N)$ in whale, meat, soya-bean and groundnut meals of dry-and wet-ground samples and available methionine $(\mathrm{g} / \mathrm{I} 6 \mathrm{~g} N)$ determined in one laboratory by Tetrahymena pyriformis $W$

\begin{tabular}{|c|c|c|c|}
\hline \multirow[b]{2}{*}{ Meal } & \multicolumn{2}{|c|}{ Available lysine } & \multirow{2}{*}{$\begin{array}{c}\text { Available } \\
\text { methionine, } \\
\text { dry-ground } \\
40 \text { mesh }\end{array}$} \\
\hline & $\begin{array}{l}\text { Dry-ground } \\
40 \mathrm{mesh}\end{array}$ & $\begin{array}{l}\text { Wet- } \\
\text { ground }\end{array}$ & \\
\hline WM 13 & $6 \cdot 8$ & $6 \cdot 6$ & $2 \cdot 5$ \\
\hline $\mathrm{SB} 2$ & $5 \cdot 4$ & $5 \cdot 3$ & $I \cdot 4$ \\
\hline SB 3 & $5 \cdot 4$ & $4 \cdot 4$ & $\mathrm{I} \cdot 4$ \\
\hline GN 8 & $3 \cdot 5$ & $3 \cdot 0$ & 0.7 \\
\hline GN 5 & $3 \cdot 2$ & $3 \cdot 3$ & $1 \cdot 0$ \\
\hline MM ro & $2 \cdot 5$ & $2 \cdot 2$ & $1 \cdot 2$ \\
\hline MM I6 & $1=5$ & $I \cdot 5$ & 0.7 \\
\hline WM 7 & 0.9 & 0.9 & 0.7 \\
\hline
\end{tabular}

The Panel was encouraged by these preliminary results and especially by the measure of interlaboratory agreement in the Strep. zymogenes assay of available methionine shown in Tables 2 and 3 , bearing in mind the relatively early state of development of the assay. It was therefore decided to pursue much more detailed collaborative tests in order to locate, and reduce if possible, sources of variation within and between laboratories and to serve the request of the parent Protein Quality Group to develop available methionine tests. 
Studies 4 and 5. Detailed studies on certain aspects of the assay of available methionine

In the collaborative studies reported here, the aspects of the Strep. zymogenes assay examined were the effects of dry- or wet-grinding the test meals, the use of crude or purified papain for predigesting the ground meals, and the adoption of optical density (OD) or titratable acidity (TA) as the bacterial growth response used to estimate the methionine available to Strep. zymogenes in the meals.

For the purpose of comparison two obvious criteria are whether the estimates obtained by the different processes agree with one another and whether one process leads to less variable estimates than another. These two features are discussed separately. At present agreement of estimates is a matter for observation and comment only. It will be of greater value in assessing the merits of one process relative to those of another when there is a reliable reference measure of available methionine for animal species against which to assess those obtained in these studies. Comparison of variability is limited in its usefulness by the extent to which the laboratories participating in these studies are representative.

In study 4 three different treatments of the meals were compared: (a) dry-ground and predigested with purified papain, $(b)$ dry-ground and predigested with crude papain, $(c)$ wet-ground and predigested with crude papain. In each laboratory OD and TA were used to estimate available methionine. Laboratories $\mathrm{B}, \mathrm{C}$ and $\mathrm{D}$ assayed two sets of samples, one mainly of vegetable origin, the other entirely of animal origin. Laboratory $\mathrm{E}$ assayed the samples of animal origin only but omitted treatment $(c)$. One further feature of this study was the inclusion of samples $\mathrm{C}_{23}$ and WM 7 in both sets in order to afford some information on the sources of variability in these assays.

In study 5 thirteen meals, including eight of animal and five of vegetable origin, were assayed. At each laboratory a sample of each meal was dry-ground and one was wet-ground and both $\mathrm{OD}$ and TA were used to estimate available methionine. The participating laboratories were B-F. Thus study 4 gave information on the enzymic predigestion, and both studies 4 and 5 were relevant to the method of grinding and the method of estimating the bacterial growth response.

It did not prove practicable to specify exactly the criteria of acceptability that each laboratory should adopt, in matters such as 'drift' of readings at different protein levels. Each laboratory used its usual methods and was asked to derive its conclusions and estimates objectively with the greatest possible care.

Summaries of the estimates of available methionine are given in Tables 5 and 6 . Each estimate given in these tables is the mean for duplicate assays.

From a preliminary examination of the results it was clear that the residual standard deviation increased with the mean available methionine so that for all the analyses reported here the variable analysed was the logarithm of estimated available methionine.

\section{Effects of treatments on agreement of estimates}

Grinding of meals. Studies 4 and 5 did not give identical results. In study 4 there was no significant effect of the method of grinding in vegetable meals, but there was in 
Table 5. Study 4. Collaborative assays in laboratories $B, C, D$ and $E$ of available methionine $(\mathrm{g} / \mathrm{1} 6 \mathrm{~g} \mathrm{~N})$ in animal and vegetable meals, measured with Streptococcus zymogenes: comparison of grinding and predigestion techniques

(Treatments: (a) sample dry-ground and predigested with purified papain; (b) sample dryground and predigested with crude papain; $(c)$ sample wet-ground and predigested with crude papain. $\mathrm{C}_{23}$ and $\mathrm{WM}_{7}$ were included in both groups)

\begin{tabular}{|c|c|c|c|c|c|c|c|c|c|c|}
\hline \multirow{2}{*}{\multicolumn{2}{|c|}{ Meal }} & & \multicolumn{2}{|c|}{ B } & \multicolumn{2}{|c|}{ C } & \multicolumn{2}{|c|}{ D } & \multicolumn{2}{|c|}{$\mathbf{E}$} \\
\hline & & & OD & $\mathrm{TA}$ & OD & $\mathrm{TA}$ & OD & $\mathrm{TA}$ & OD & $\mathrm{TA}$ \\
\hline \multirow[t]{3}{*}{$\mathrm{SB}$} & 2 & (a) & $I \cdot 4 I$ & $1 \cdot 29$ & $I \cdot 49$ & $I \cdot 32$ & $I \cdot 45$ & $I \cdot 20$ & - & - \\
\hline & & (b) & $I \cdot 43$ & I'34 & I. 36 & $I \cdot 25$ & $1 \cdot 30$ & $I \cdot I 5$ & - & 一 \\
\hline & & & $I \cdot 42$ & $1 \cdot 24$ & 一 & - & $1 \cdot 35$ & $I \cdot I 5$ & - & - \\
\hline \multirow[t]{3}{*}{$\mathrm{SB}$} & 3 & (a) & $I \cdot I 6$ & 1.04 & I 00 & I'I 5 & 0.97 & 0.99 & - & 一 \\
\hline & & (b) & $I \cdot 30$ & I.09 & 0.95 & $I \cdot I 2$ & 0.90 & 0.93 & - & - \\
\hline & & (c) & $I \cdot 26$ & 1.06 & 一 & - & 0.98 & 0.97 & - & 一 \\
\hline \multirow[t]{3}{*}{ GN } & 5 & (a) & 0.83 & 0.76 & 0.72 & 0.72 & 0.84 & $1 \cdot 00$ & - & - \\
\hline & & (b) & 0.84 & 0.70 & 0.63 & 0.71 & $0.7^{8}$ & 0.63 & - & 一 \\
\hline & & (c) & 0.91 & 0.71 & 一 & 一 & 0.83 & 0.66 & - & - \\
\hline \multirow{3}{*}{ GN } & 8 & (a) & $1 \cdot 24$ & I.04 & $\mathrm{I} \cdot \mathrm{OI}$ & $I \cdot I 3$ & 1.00 & 0.94 & - & - \\
\hline & & (b) & $1 \cdot 29$ & 0.99 & 0.98 & 1.02 & 0.95 & 0.88 & - & - \\
\hline & & $(c)$ & $I \cdot 39$ & $1 \cdot 03$ & 一 & - & I.00 & 0.93 & - & - \\
\hline \multirow{3}{*}{\multicolumn{2}{|c|}{$\mathrm{C}_{23}$}} & (a) & $3 \% 5$ & 3.30 & $2 \cdot 88$ & 3.08 & $3 \cdot 10$ & $3 \cdot 10$ & - & - \\
\hline & & (b) & $2 \cdot 89$ & $2 \cdot 8 I$ & $2 \cdot 74$ & 3.09 & 3.30 & 2.80 & - & - \\
\hline & & $(c)$ & $3 \cdot 17$ & $2 \cdot 93$ & - & - & 2.80 & 3.00 & - & - \\
\hline \multirow[t]{3}{*}{ WM } & 7 & (a) & 0.47 & 0.40 & 0.48 & 0.49 & 0.52 & 0.43 & - & - \\
\hline & & $(b)$ & 0.47 & 0.37 & 0.33 & $0.3^{8}$ & 0.43 & 0.35 & - & - \\
\hline & & $(c)$ & 0.63 & 0.52 & 一 & - & 0.58 & 0.45 & - & $\cdots$ \\
\hline \multirow[t]{3}{*}{ WM } & 7 & (a) & 0.43 & 0.46 & 0.30 & 0.36 & 0.42 & 0.41 & 0.63 & 0.50 \\
\hline & & (b) & 0.51 & 0.42 & 0.26 & $0.3^{6}$ & 0.41 & 0.34 & 0.47 & 0.34 \\
\hline & & (c) & 0.58 & 0.56 & $0.3^{6}$ & 0.35 & 0.48 & 0.42 & 一 & - \\
\hline \multirow{3}{*}{\multicolumn{2}{|c|}{ WM I3 }} & (a) & $2 \cdot 55$ & 2.50 & $2 \cdot 16$ & $2 \cdot 29$ & $2 \cdot 10$ & 2.10 & $2 \cdot 72$ & $2 \cdot 70$ \\
\hline & & (b) & $2 \cdot 82$ & $2 \cdot 22$ & $2 \cdot 11$ & $2 \cdot 10$ & $I \cdot 80$ & $I-90$ & I.98 & $2 \cdot 01$ \\
\hline & & $(c)$ & $2 \cdot 3^{8}$ & $2 \cdot 60$ & $2 \cdot 23$ & $2 \cdot 20$ & $2 \cdot 00$ & $I \cdot 90$ & - & - \\
\hline \multirow{3}{*}{\multicolumn{2}{|c|}{ MM го }} & (a) & 0.71 & 0.61 & 0.54 & 0.51 & 0.63 & 0.55 & $0.8 \mathrm{I}$ & 0.69 \\
\hline & & (b) & 0.76 & 0.54 & 0.33 & 0.28 & 0.62 & 0.47 & 0.68 & 0.45 \\
\hline & & $(c)$ & 0.85 & $0.6 I$ & 0.54 & 0.54 & 0.68 & 0.52 & - & - \\
\hline \multirow{3}{*}{\multicolumn{2}{|c|}{ MM I6 }} & (a) & 0.44 & 0.32 & 一 & 一 & 0.41 & 0.29 & 0.47 & $0.3^{8}$ \\
\hline & & (b) & 0.43 & 0.27 & - & - & 0.35 & 0.25 & $0.3^{6}$ & 0.29 \\
\hline & & $(c)$ & 0.50 & 0.25 & 一 & 一 & 0.42 & 0.27 & - & $\cdots$ \\
\hline \multirow{2}{*}{\multicolumn{2}{|c|}{$\mathrm{C}_{23}$}} & (a) & 3.14 & $\begin{array}{l}3.00 \\
2.85\end{array}$ & 2.91 & $2 \cdot 9 \mathrm{I}$ & $2 \cdot 80$ & 3.00 & 3.37 & $3.3 I$ \\
\hline & & & $\begin{array}{l}3 \cdot 15 \\
3 \cdot 16\end{array}$ & $\begin{array}{l}2.85 \\
3.00\end{array}$ & $\begin{array}{l}2 \cdot 68 \\
2.72\end{array}$ & $\begin{array}{l}2 \cdot 72 \\
2 \cdot 88\end{array}$ & $\begin{array}{l}2 \cdot 60 \\
2 \cdot 80\end{array}$ & $\begin{array}{l}2 \cdot 90 \\
2 \cdot 90\end{array}$ & 2.57 & $\begin{array}{c}3.24 \\
-\end{array}$ \\
\hline
\end{tabular}

OD, assessed by optical density; TA, assessed by titratable acidity.

animal meals, whereas in study 5 at the higher papain level very little change resulted in either vegetable or animal meals. The results are given in Table 7 . The tendency was for wet-grinding to give a higher estimate of available methionine. There were significant $(P<0.05)$ differences between the participating laboratories in the effect of the method of grinding, as illustrated in Table 8. From Tables 7 and 8 it is clear that there was considerable variation in the effect of grinding, ranging from $16 \%$ in favour of wet-grinding to $4 \%$ in favour of dry-grinding. 
Vol. 2I

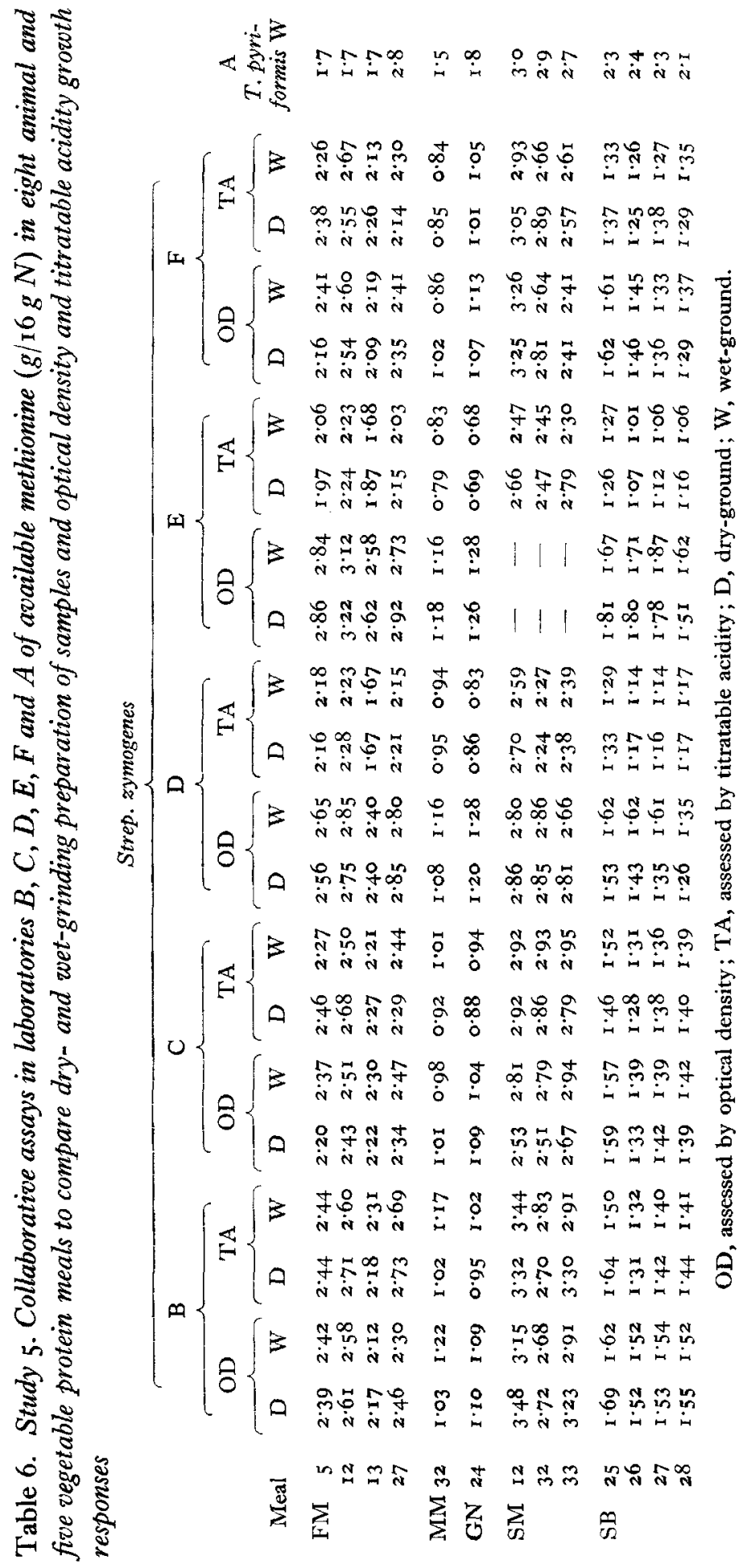




\section{i94 A. W. Boyne, S. A. Price, G. D. Rosen and J. A. Stott ig67}

Enzymic predigestion. When either method of assessment was employed (OD or TA) the difference between estimated available methionine was similar from one vegetable meal to another or from one animal meal to another. In Table 9 the mean differences of $\log$ available methionine are given for each centre, using each method of assessment.

Our results showed that the use of a purified papain gave higher results than did the use of a crude preparation at the same concentration. In addition we noted that the difference was greater with animal than with vegetable meals, as it was when TA rather than OD was the method of assessment, and that the effect of the type of papain was not consistent from one laboratory to another.

\section{Table 7. Studies 4 and 5. Effect of method of grinding on available methionine estimates}

(Values given are the mean differences between the logarithms of the estimates together with their standard errors; the corresponding estimate on the wet-ground sample, expressed as a percentage of the estimate on the dry-ground sample, is given in parentheses)

\begin{tabular}{|c|c|c|c|c|}
\hline \multirow[b]{2}{*}{ Study } & \multicolumn{2}{|c|}{ Vegetable proteins } & \multicolumn{2}{|c|}{ Animal proteins } \\
\hline & OD & $\mathrm{TA}$ & OD & $\mathrm{TA}$ \\
\hline 4 & $\begin{array}{l}\text { O.0I } 3 \pm 0.01 I \\
(103 \%)\end{array}$ & $\begin{array}{l}\text { O.01 } 5 \pm 0.013 \\
(104 \%)\end{array}$ & $\begin{array}{l}0.052 \pm 0.010 \\
(1 \pm 3 \%)\end{array}$ & $\begin{array}{c}0.066 \pm 0.010 \\
(116 \%)\end{array}$ \\
\hline 5 & $\begin{array}{c}0.005 \pm 0.005 \\
(101 \%)\end{array}$ & $\begin{array}{c}-0.005 \pm 0.005 \\
(99 \%)\end{array}$ & $\begin{array}{c}0.004 \pm 0.004 \\
(101 \%)\end{array}$ & $\begin{array}{c}-0.009 \pm 0.004 \\
(98 \%)\end{array}$ \\
\hline
\end{tabular}

\section{rable 8. Study 5. Differences between laboratories in the effect of method of grinding on available methionine estimates}

(Values given are the mean differences log available methionine after wet-grinding less log available methionine after dry-grinding; the corresponding mean for wet-grinding, expressed as a percentage of that for dry-grinding, is given in parentheses)

Laboratory

$\begin{array}{cc}\text { B } & 0.007(102 \%) \\ \text { C } & -0.015(97 \%) \\ \text { D } & -0.018(96 \%) \\ \text { E } & 0.008(102 \%) \\ \text { F } & -0.004(99 \%) \\ \text { Standard errors of differences } & \pm 0.0075 \\ \text { between laboratories } & \end{array}$

TA

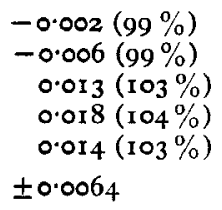

OD, assessed by optical density; TA, assessed by titratable acidity.

Method of measurement of response. In general, the use of OD gave higher estimates of available methionine than did TA. This is illustrated in Table $\mathrm{r} O$, which gives the difference of $\log \mathrm{OD}-\log \mathrm{TA}$ for each meal separately. In both studies the estimate using OD was higher $(P<0.001)$ than that obtained by TA. This difference was not consistent, however, and depended upon the meal tested $(P<0.001)$, ranging from a difference of $4 \%$ in favour of TA to a difference of $38 \%$ in favour of OD. It was also apparent that the difference varied from one laboratory to another $(P<0 \circ 001)$. (In the analyses of these results the unweighted means for each meal at each laboratory were analysed and the meal $\times$ laboratory interaction was used to assess the significance of laboratory or meal differences.) 


\section{Table 9. Study 4. Effect of enzymic predigestion on available methionine estimates}

(Values in the table are the mean differences $\log$ available methionine after purified papain predigestion less log available methionine after crude papain predigestion and their standard errors, with, in parentheses, the corresponding estimate of available methionine after predigestion with purified papain, expressed as a percentage of the estimate after predigestion with crude papain)

$$
\begin{array}{ccc}
\text { Laboratory } & \text { OD } & \text { TA } \\
& \text { Vegetable meals } \\
\text { B } & -0.010 \pm 0.014(98 \%) & 0.021 \pm 0.019 \\
\text { C } & 0.033 \pm 0.011(108 \%) & 0.018 \pm 0.008 \\
\text { D } & 0.022 \pm 0.016(105 \%) & 0.066 \pm 0.018 \\
\text { Mean } & 0.015 \pm 0.008(104 \%) & 0.035 \pm 0.009 \\
& \multicolumn{2}{c}{\text { Animal meals }}
\end{array}
$$

$\begin{array}{ccc}\text { B } & -0.010 \pm 0.014(98 \%) & 0.021 \pm 0.019(105 \%) \\ \text { C } & 0.033 \pm 0.011(108 \%) & 0.018 \pm 0.008(104 \%) \\ \text { D } & 0.022 \pm 0.016(105 \%) & 0.066 \pm 0.018(116 \%) \\ \text { Mean } & 0.015 \pm 0.008(104 \%) & 0.035 \pm 0.009(108 \%)\end{array}$

$\begin{array}{ccc}\text { B } & -0.022 \pm 0.018(95 \%) & 0.048 \pm 0.025(112 \%) \\ \text { C } & 0.079 \pm 0.012(120 \%) & 0.113 \pm 0.014(130 \%) \\ \text { D } & 0.024 \pm 0.019(106 \%) & 0.060 \pm 0.010(115 \%) \\ \text { E } & 0.114 \pm 0.011(130 \%) & 0.122 \pm 0.031(132 \%) \\ \text { Mean } & 0.049 \pm 0.008(112 \%) & 0.086 \pm 0.011(122 \%)\end{array}$

$\mathrm{OD}$, assessed by optical density; TA, assessed by titratable acidity.

\section{Table 10. Effect of method of measurement of response on available methionine estimates}

(Values given in $(a)$ are means of $\log$ OD - $\log$ TA averaged over all laboratories for each meal. In parentheses the corresponding estimates obtained by $O D$ are given as percentages of

\begin{tabular}{|c|c|c|c|c|c|c|}
\hline & & Study & & & Study & \\
\hline \multicolumn{2}{|l|}{ Meal } & \multicolumn{2}{|c|}{$\log \mathrm{OD}-\log \mathrm{TA}$} & Meal & \multicolumn{2}{|c|}{$\log O D-\log T A$} \\
\hline & & & & & & \\
\hline & 2 & 0.055 & $(114 \%)$ & FM & 0.040 & $(110 \%)$ \\
\hline & 3 & -0.003 & $(99 \%)$ & $\mathrm{FM}$ & 0.044 & $(I I I \%)$ \\
\hline GN & 5 & 0.026 & $(106 \%)$ & FM 1 & 0.060 & $(115 \%)$ \\
\hline GN & & 0.032 & $(108 \%)$ & FM 27 & 0.046 & $(111 \%)$ \\
\hline WM & & 0.040 & $(110 \%)$ & $\mathrm{MM}_{32}$ & 0.068 & $(1 \times 7 \%)$ \\
\hline WM I & & -0.004 & $(99 \%)$ & SM & 0.038 & $(100 \%)$ \\
\hline MM I & & 0.096 & $(125 \%)$ & SM & 0.038 & $(100 \%)$ \\
\hline $\mathrm{MM}_{\mathrm{I}}$ & & 0.141 & (138\%) & $\mathrm{SM}$ & 0.032 & $(108 \%)$ \\
\hline & 3 & -0.016 & $(96 \%)$ & SB 2 & 0.072 & $(1 \mathrm{1} 8 \%)$ \\
\hline \multirow{5}{*}{\multicolumn{2}{|c|}{ Mean }} & 0.041 & $(110 \%)$ & $\mathrm{SB} \quad 2$ & 0.100 & $(126 \%)$ \\
\hline & & & & SB & 0.078 & $(120 \%)$ \\
\hline & & & & $\mathrm{SB} \quad 28$ & 0.049 & $(112 \%)$ \\
\hline & & & & GN 2 & 0.118 & $(131 \%)$ \\
\hline & & & & Mean & 0.060 & $(15 \%)$ \\
\hline
\end{tabular}
the estimates obtained by TA. In $(b)$ the means and percentages for laboratories are given averaged over all meals)

Approximate standard error of individual means is \pm 0.01 I (based on meal $\times$ laboratory interaction).

(b) Means for laboratories

$\begin{array}{cccccc}\text { Study } & \text { B } & \text { C } & \text { D } & \text { E } & \text { F } \\ 4 & 0.068(117 \%) & -0.003(99 \%) & 0.041(110 \%) & 0.058(114 \%) & - \\ 5 & 0.007(102 \%) & 0.002(100 \%) & 0.098(125 \%) & 0.173(149 \%) & 0.022(105 \%)\end{array}$

Approximate standard error of differences is \pm 0.0065 (based on meal $\times$ laboratory interaction). $O D$, value assessed by optical density; TA, value assessed by titratable acidity. 
Effects of treatments on variability of estimates

The residual mean squares, which would be used for comparing estimates obtained in the same replicate at any centre, are given in Table I I. Because of the variability in these mean squares it is not possible to state with any certainty what the standard error of an estimate would be, nor can it be concluded that any method of preparation of the samples is consistently more reliable than another except perhaps that in study 4 predigestion with purified papain seemed to lead to consistently less variability, whether assessment was on the basis of OD or of TA. The variability did not appear to be a characteristic of the laboratory either, since at laboratory $\mathrm{C}$, for example, the residual mean squares were large in study 4 when crude papain was used, and in study 5 they were among the smallest.

Variability tended to be smaller and more uniform between laboratories in study 5 when OD was used, and it made little difference to the variability whether the meal was wet- or dry-ground.

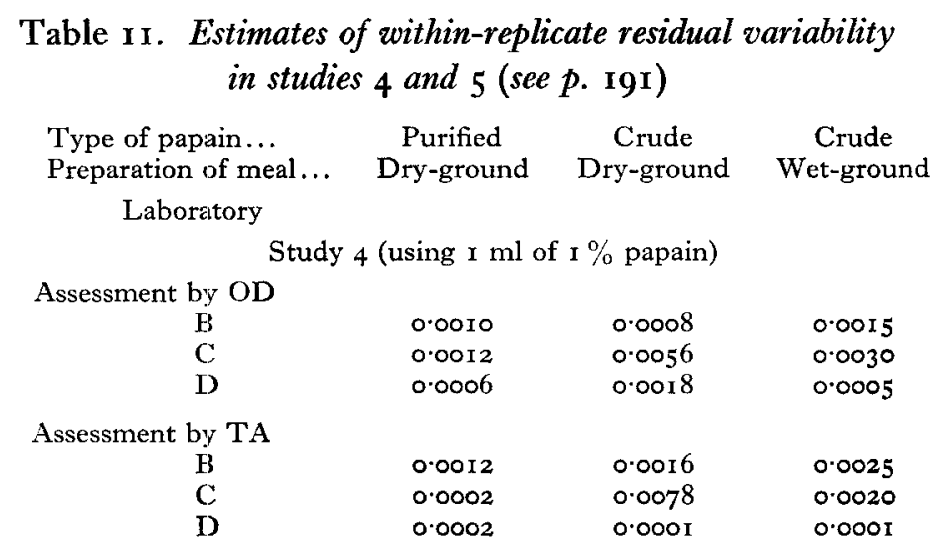

$\begin{array}{cccc}\text { Assessment by OD } & & \\ \text { B } & - & 0.0007 & 0.0009 \\ \text { C } & - & 0.0007 & 0.0004 \\ \text { D } & - & 0.0014 & 0.0011 \\ \text { E } & - & 0.0008 & 0.0006 \\ \text { F } & & & 0.00091 \\ \text { Assessment by TA } & - & 0.0003 & \\ \text { B } & - & 0.0003 & 0.0005 \\ \text { C } & - & 0.0022 & 0.0013 \\ \text { D } & - & 0.0029 & 0.0031 \\ \text { E } & 0.0032 & 0.0023 \\ \text { F } & & \end{array}$

WM 7 and $\mathrm{C}_{23}$ had been included in both sets of assays in study 4 as a potential aid to partitioning the causes of variability (i.e. within replicates, between replicates within laboratories and between laboratories), but the within-replicate variability was so different from one laboratory to another that this partition was not practicable. 
A further examination was carried out of the variability in study 5 . The residual mean square was calculated at each laboratory for each of the four types of assays: dry-ground meals and wet-ground meals assessed by OD and TA. The logarithms of the mean squares were analysed, and this led to the conclusion that there was no significant effect of the method of preparation of the meals on residual variability but that there was a significant $(P<0.05)$ laboratory response criterion interaction. This can be interpreted with the aid of Table I I to indicate that when OD was the method of assessment the mean square was fairly uniform from one laboratory to another but that, when TA was used, at some laboratories the variability was large relative to that obtaining when OD was used and at others it was small.

\section{DISCUSSION}

To consider, generally facilitate and develop microbiological assay methods in the field of protein quality are the basic aims of the Microbiological Panel. In this context a number of features emerge from the exploratory and preliminary work, aimed essentially towards the rapid assay of biological features of protein quality not revealed by chemical analysis.

The work provided further confirmation and extensions of the significant correlations previously noted between microbiological responses to protein quality and published values obtained with animals (chick GPvs and rat assays) on samples of the specially stored Agricultural Research Council meals. This agreement inspired confidence in the steps towards the development of assays of the availabilities of single amino acids; such assays are sought increasingly by both animal and human nutritionists.

Amongst the exploratory studies carried out were experiments in which the responses to amino acid supplementation were examined. The response of Strep. zymogenes to single and multiple amino acid supplementations of animal proteins was unfamiliar by comparison with that of higher animals, as has been subsequently discussed in some detail by Waterworth (1964). Single amino acid responses of relative nutritive values were sometimes difficult to demonstrate, for example in whale and meat meals. Isoleucine, leucine, valine and arginine responses, singly and in pairs, were observed for fish meals as compared with lysine and methionine-cystine effects commonly observed in animals. Increases of relative nutritive values, often by up to $50-100 \%$ were also manifest. These differences between the bacterial and animal patterns could well derive from different qualitative and quantitative patterns of amino acid requirement.

The picture for $T$. pyriformis $\mathrm{W}$ was somewhat akin to the usual animal pattern of amino acid response to methionine for fish and soya-bean and to lysine for meat and groundnut. There is evidence for $T$. pyriformis $\mathrm{W}$ that, as with higher animals (Anantharaman \& Carpenter, 1965 ), heat damage to vegetable proteins, notably soya, can cause a change from a methionine to a lysine deficiency (G. D. Rosen, J. A. Stott $\& \mathrm{H}$. Smith, personal communication).

All the microbiological tests reported here and previously on the three fish meals selected for feeding trials with pigs, chicks and rats (Barber et al. r964; Bunyan \& 
Woodham, 1964) served to distinguish clearly between good and bad. The criteria for the micro-organism tests were: relative nutritive value and available methionine for Strep. zymogenes, and nutritive value, available methionine and available lysine for T. pyriformis $\mathrm{W}$.

Considering the range of four different series of meals tested and the early stage of development of the Strep. zymogenes assay, the interlaboratory agreements found and reported in Table 2 on the preliminary total and available methionine testing were most encouraging to the Panel and led to the decision to try to define a standard procedure for the availability test. This applied even in the face of the known technical difficulties in working with vegetable protein materials.

The higher values obtained for available methionine with $T$. pyriformis $\mathrm{W}$ in these studies may be suggestive of a more vigorous proteolytic system in the protozoon. This could also account at least in part for the observation in these and other studies that finer grinding of feeding-stuffs does not increase growth response as it does for Strep. zymogenes. But it is of interest that the available methionine content of a somewhat unconventional feeding-stuff, the leaf protein concentrate preparation, was increased for $T$. pyriformis $W$ by wet-grinding before assay from 0.5 to $\mathrm{I} \cdot 9 \mathrm{~g} / \mathrm{r} 6 \mathrm{gN}$. It should perhaps be stressed that only one laboratory conducted work with $T$. pyriformis during the period reported, and there was no measure therefore of betweenlaboratory variation for the protozoal test. Celliers (196I) has previously reported that the $T$. pyriformis $\mathrm{W}$ assay seemed to have good reproducibility, and Teunisson (196I) and Baum \& Haenel (1965) have more recently reported favourably on its value in studies of protein quality for a wide range of feeding-stuffs and foods. Available methionine contents determined by $T$. pyriformis $W$ for the thirteen samples in study 5 (see Table 6) were substantially higher than the Strep. zymogenes values for meat, soya-bean and groundnut and about equal for milk powders, but for three out of four fish meals they were lower; more work will be needed to discover the significance of such observed differences.

The major studies in this collaborative series were studies 4 and 5 on the estimation of available methionine contents by Strep. zymogenes, tracing the effects of certain variables of technique on the results and their variability.

Statistical analysis showed no consistently significant effect of wet- versus drygrinding of the sample on the estimates, although the tendency was for the former to increase the values very slightly. Hence the Panel decided to retain dry-grinding through a $4^{0-m e s h}$ screen in its suggested procedure as likely to be more acceptable, particularly for routine analytical work. Only with very low-quality protein materials such as WM 7 and MM I6 was the available methionine value considerably increased by grinding. This is reported to be true also for blood meals of low nutritive value (S. A. Price and L. Gare, personal communication).

Estimates of available methionine by Strep. zymogenes were increased significantly by the use of refined compared with crude papain, on an equal weight basis, for the necessary predigestion in sample preparation; this is in agreement with the findings of Miller, Carpenter, Morgan \& Boyne (1965) and of Ford (1964). The importance of standardizing proteolytic activity in the assay has been stressed also by Rao, Sreenivas, 
Swaminathan, Carpenter \& Morgan ( 1963 ) and by Miller, Carpenter \& Milner (1965). Purified papain is free from methionine, which is advantageous for this assay, but it is very expensive. Tests with an eightfold increase of the crude papain concentration gave results as high as did the purified papain, and this procedure was the routine adopted therefore in study 5. It has also been adopted as the method of sample preparation in our suggested provisional method and has recently been reported by Miller, Carpenter, Morgan \& Boyne ( 1965$)$ to afford the best agreement (less by an average of $9 \%$ ) with chick estimates of available methionine.

In the statistical analysis it was noted also that the effect of the enzyme was greater with animal than with vegetable meals and also when titratable acidity, as against optical density, was used. Furthermore, the effect of type of papain was not consistent from one laboratory to another. In view of the strong influence of the predigestion procedure on the results of assays for available methionine, this particular aspect of the Strep. zymogenes technique should obviously be given further study when other amino acids, or types of sample other than those reported on here, are to be considered. No correction was made in laboratories $\mathrm{D}$ and $\mathrm{F}$ for any methionine in the additional $8-12 \% \mathrm{~N}$ contributed by the enzymes, but in the other laboratories blank corrections were made. In future work it would be desirable to make a routine blank correction.

In general, optical density gave very significantly higher estimates of available methionine than did titratable acidity, by approximately $15 \%$ on the average. But the difference was inconsistent, being highly significantly dependent on the meal tested (ranging from $-4 \%$ to $+38 \%$ in favour of optical density) and it varied significantly from one laboratory to another. It is of interest in this connexion that one laboratory reported that the use of TA instead of OD necessitated working over a different dosage range and this could in part be responsible for the observed interlaboratory differences.

To some extent, spuriously higher results calculated from turbidity readings might be expected because of the possibility of a residual opacity of the test preparations; with samples of low protein content especially, the test digests were often turbid. There seemed no obvious means of correcting for this, except by assessing the growth responses indirectly from measurements of titratable acidity.

From the analysis of variability there was some evidence slightly in favour of optical density as yielding for these samples more uniformly precise results, but it could not be concluded that any one of the sample preparation procedures is consistently the most reliable.

If the residual mean square is averaged over the five laboratories using the results derived from crude dry-ground meals assessed by $O D$ this leads to a standard error of the difference between the logarithms of the estimates for two meals of \pm 0.04 . The implication is that on average one might expect to detect in a given laboratory a difference of about $20 \%$ in the available methionine content of two meals at the $5 \%$ level of significance.

There were obviously differences between laboratories and between methods of preparation and assessment in the estimates of available methionine. These can be seen from an examination of Tables 5 and 6 . In consequence greater errors are attached 
to differences between estimates obtained either at different laboratories or at the same laboratory on different occasions, but it is not possible to estimate these errors

It can also be seen from Table 5 that where the use of a method of preparation at : laboratory gave high estimates of available methionine in $\mathrm{C}_{23}$ and WM 7 it alsc tended to give high estimates for the other meals, although this was not always so This observation, along with the general conclusions derived from studies 4 and 5 suggests two alternative courses of action; these may indeed be complementary. Thr first is that further information should be sought on the reasons for the difference: found between laboratories and for differences between replicate assays at the samı laboratory. The second is that until more is known of the reasons for these difference: it might be useful to include in the assay of a series of meals one or more standard of known value to the animal as reference sources of methionine against which t calibrate the other materials. Although the Strep. zymogenes assay is relatively success ful in grading meals as sources of available methionine there is still some way to go it determining how reliably the results of an assay provide estimates of the absolut values of methionine available to Strep. zymogenes.

No general recommendation, therefore, can be offered. For samples of low proteir content yielding highly turbid test digests, or for strongly coloured materials such a leaf protein concentrate, blood meal, cottonseed and sun-flower meals photometri measurement of growth responses would be inappropriate. For many protein-ricl foodstuffs it would be convenient to assess growth responses photometrically. In th longer term, however, it may prove to be more appropriate and rewarding to estimat the Strep. zymogenes response by the titration procedure because it will be possible $t$ apply the procedure more easily to a wider range of protein sources, including cerea and high-starch foods, compound animal feeds and baked goods along the line followed recently by Saunders \& McFadyen (1964).

The necessity to predigest the test proteins is a disadvantage of the Strep. zymogene method as compared with the Tetrahymena method, in which no such partial hydrolysi: is advocated. Besides speeding growth and improving the linearity of the doseresponse curves, the enzymic predigestion gives markedly higher assay values that are obtained when the test proteins are simply suspended in aqueous buffer (Ford 1964); the conditions of the enzymic predigestion are important in determining th answers obtained. It might be supposed that, since a predigestion procedure is neces sary, there is no advantage in the use of a proteolytic micro-organism such as Strep zymogenes for the microbiological assays and that similar results might be expecter from the assay of the enzymic digests either chemically or with non-proteolytic micro organisms. In practice, however, the enzymic hydrolysis is far from complete, eve1 with digestible proteins of high quality, and Ford (1964) found large difference between the measured methionine content of enzymic digests of food proteins accord ing to whether proteolytic or non-proteolytic micro-organisms were employed in th microbiological test.

In arriving at the procedure detailed in Appendix A, the Panel has been influencer by the need for consistent estimates of available methionine. Where evidence existed it appeared that the higher the microbiological estimate the better it agreed with suc] 
results as could be obtained from animal studies, but the sparsity of values obtained with animals for direct comparison has hindered progress. It must be stated in defining a provisional method (and no doubt in defining others to follow for other materials and organisms) that our knowledge of the nutritional requirements of different species is as yet too rudimentary to allow us to provide guidance on how to apply, for example, the microbial assay of available methionine to practical problems, or indeed how to use the results in compounding of feeding-stuffs. We cannot yet be certain that values obtained in the microbiological assays will represent the availability of the amino acids for higher animals, which may itself vary substantially with the species of test animal, the dietary environment of the protein(s) under test and the nutritive response under consideration, as do indeed the conventional biological criteria of protein quality.

Much more comparative biological and microbiological testing needs to be done on a wider variety of food proteins before we shall be able to define optimal procedures for the microbiological tests.

We recognize, however, that the practical application of nutritive values of protein as such and of availabilities of individual amino acids measured with micro-organisms or higher animals must involve the extension of the work on protein concentrates more and more to cereals and their admixtures in complex diets. The Panel is now giving its attention to the technical problems involved. It is likely that no one microbiological assay procedure can meet all needs, just as no single form of protein quality rating for higher animals can specify the nutritive value of dietary protein under all conditions of feeding. The limitations of total amino acid analysis are, however, becoming more and more apparent and it is hoped that the new microbiological methods for measuring amino acid availability will eventually give the feedings-stuffs manufacturer a more valid insight into, and accurate indication of, the most economic contribution each protein can make towards meeting the amino acid needs of the animal species concerned and how best to avoid damage to natural protein resources by suboptimal processing.

\section{APPENDIX A}

\section{Provisional method for the assay of available methionine with}

\section{Strep. zymogenes}

The standardized method evolved was based on that described by Ford ( 1962 , 1964) modified with regard to the concentration of papain used for predigestion of the test meals (Miller, Carpenter \& Milner, 1965). This method is set out below.

\section{Reagents}

Assay medium. Prepare the assay medium from two stock solutions-the basal medium and the amino acid supplement-made up as described in Appendix Table 1. Store the stock solutions at $-20^{\circ}$. When required for use, thaw the stock solutions and warm the amino acid supplement to dissolve the precipitate; then combine them in the proportion of two volumes basal medium to one volume amino acid supplement. 
Table I

Basal medium

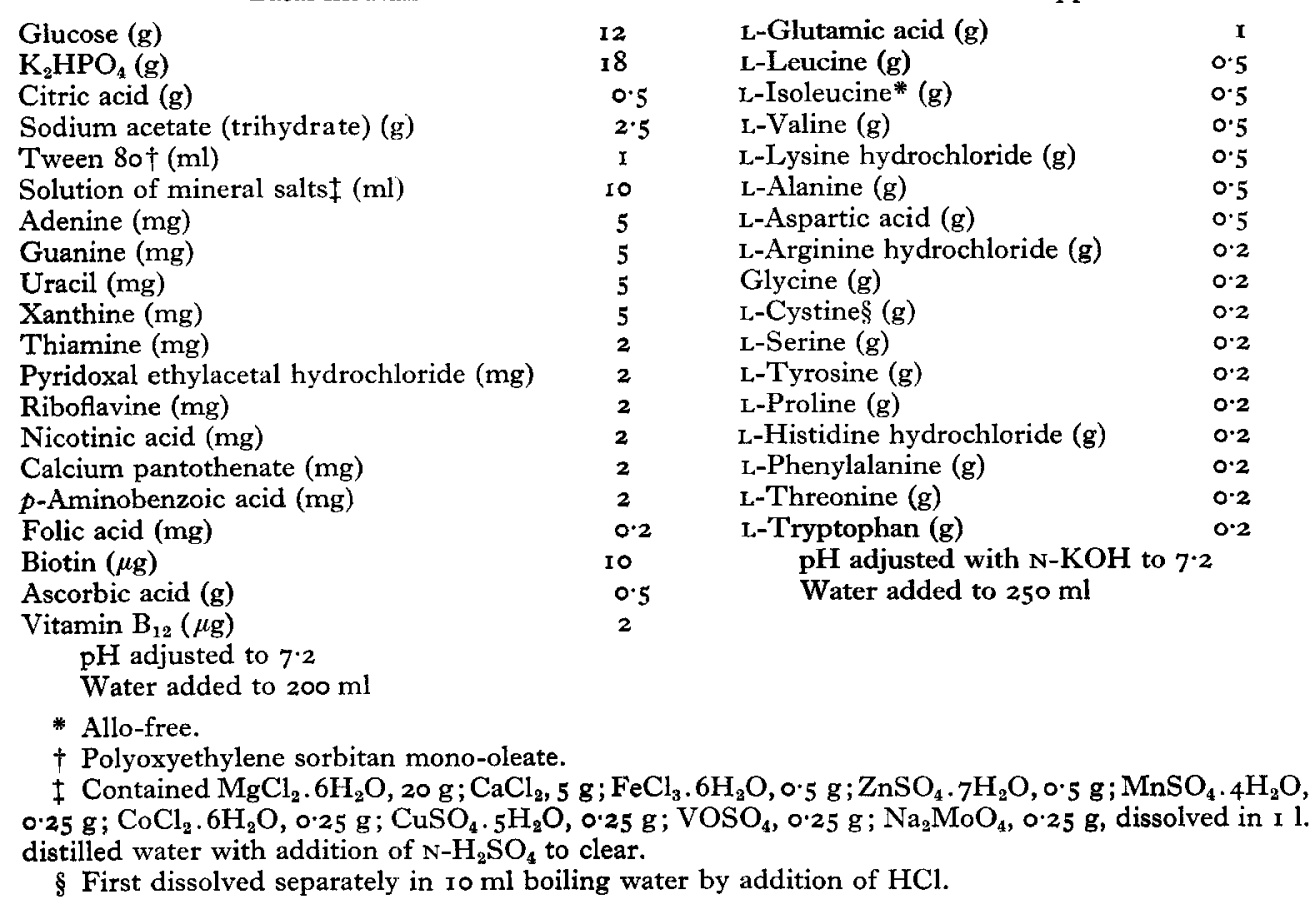

Casein-glutamate-agar stabs

$\begin{array}{lr}\text { Basal medium } & 20 \mathrm{ml} \\ \text { Casein } & \text { I } 50 \mathrm{mg} \\ \text { Sodium glutamate } & \text { I } 5 \mathrm{mg} \\ \text { Agar } & 1 \cdot 5 \mathrm{~g} \\ \text { Distilled water to } & 100 \mathrm{ml}\end{array}$

Steam to dissolve the agar, and dispense in $10 \mathrm{ml}$ volumes. Autoclave at 1 I $5^{\circ}$ for $15 \mathrm{~min}$.

Transfer medium

$\begin{array}{lc}\text { Basal medium } & 20 \mathrm{ml} \\ \text { Tryptone (Oxoid Limited) } & 200 \mathrm{mg} \\ \text { Distilled water to } & 100 \mathrm{ml}\end{array}$

Dispense in $10 \mathrm{ml}$ volumes. Autoclave at $\mathrm{II}_{5}^{\circ}$ for ${ }_{5} \mathrm{~min}$.

Inoculum medium

$\begin{array}{lr}\text { Basal medium } & 20 \mathrm{ml} \\ \text { Casein } & \text { I } 50 \mathrm{mg} \\ \text { Sodium glutamate } & \text { I } 5 \mathrm{mg} \\ \text { Distilled water to } & \text { I00 } \mathrm{ml}\end{array}$

Dispense in $10 \mathrm{ml}$ volumes. Autoclave at $115^{\circ}$ for $15 \mathrm{~min}$. 
Citrate cyanide buffer

$\begin{array}{lc}\text { Trisodium citrate } & 5 \mathrm{~g} \\ \text { Sodium cyanide } & 30 \mathrm{mg}\end{array}$

Dissolve in distilled water, adjust $\mathrm{pH}$ to $7 \cdot 2$ with $\mathrm{N}-\mathrm{H}_{3} \mathrm{PO}_{4}$ and dilute to $1000 \mathrm{ml}$. Standard methionine solution. Accurately weigh $200 \mathrm{mg}$ of pure L-methionine (L. Light and Co., Colnbrook, Bucks.) and dissolve it in aqueous solution containing Io $\%(\mathrm{v} / \mathrm{v})$ ethanol. Dilute to $100 \mathrm{ml}$ with $10 \%(\mathrm{v} / \mathrm{v})$ aqueous ethanol to give a strong standard solution containing $2 \mathrm{mg}$ methionine/ml. Store at $4^{\circ}$. On the day of assay pipette $\mathrm{x} \cdot 0 \mathrm{ml}$ of this solution into a $200 \mathrm{ml}$ volumetric flask and dilute to volume with distilled water to give a dilute standard solution containing Io $\mu \mathrm{g} \mathrm{L}$-methionine $/ \mathrm{ml}$.

\section{Organism maintenance and inocula}

Streptococcus zymogenes NCDO 592 obtained from the National Culture of Dairy Organisms of the National Institute for Research in Dairying was the organism used.

Maintain the stock culture by monthly transfer from the stab culture (on caseinglutamate-agar medium) to the transfer medium; incubate overnight at $37^{\circ}$ and use this culture to inoculate a fresh stab culture. Incubate overnight at $37^{\circ}$ and store at $4^{\circ}$.

To prepare inoculum for the assay, subculture from a freshly grown transfer medium culture to a tube of inoculum medium; incubate overnight at $37^{\circ}$. Subsequent inocula may be prepared by daily transfer from the inoculum culture.

\section{Procedure}

Preparation of samples for tests. Grind the sample to pass a 40-mesh sieve. Accurately weigh that amount of sample that contains roo $\mathrm{mg} \mathrm{N}$ into a stoppered container and suspend it in $20 \mathrm{ml}$ of citrate-cyanide buffer. Adjust the $\mathrm{pH}$ to $7 \cdot 2$ and place the container in a water bath at $56^{\circ}$. Add $2 \mathrm{ml}$ of $4 \%(\mathrm{w} / \mathrm{v})$ crude papain (British Drug Houses Ltd)* or equivalent in citrate-cyanide buffer at $\mathrm{pH} 7 \cdot 2$ and incubate with continuous (or intermittent) shaking for $3 \mathrm{~h}$ at $56^{\circ}$. Cool, adjust the $\mathrm{pH}$ and dilute to I00 $\mathrm{ml}$ (i.e. I $\mathrm{mg} \mathrm{N} / \mathrm{ml}$ ).

Determination of available methionine. Dilute the hydrolysates to contain approximately Io $\mu \mathrm{g}$ methionine $/ \mathrm{ml}$.

Distribute $0, \mathrm{I} \cdot 0,2 \cdot 0,4 \cdot 0,6 \cdot 0$ and $8 \cdot 0 \mathrm{ml}$ portions of the dilute standard methionine solution into $6 \times \frac{3}{4}$ in optically matched Pyrex test-tubes. Similarly, distribute $r \cdot 0$, $2 \cdot 0,4 \cdot 0,6 \cdot 0$ and $8 \cdot 0 \mathrm{ml}$ portions of the diluted hydrolysates into a second series of test tubes. Use two tubes for each different volume of the standard and sample respectively. Add $3 \mathrm{ml}$ of the assay medium to each tube and distilled water to bring the final volume to II ml. Mix the contents thoroughly by careful shaking. Cover each tube with an aluminium cap and sterilize by steaming for $20 \mathrm{~min}$.

Cool in a water bath to $37^{\circ}$, add one drop of undiluted inoculum culture to each tube and incubate at $37^{\circ}$ for $48 \mathrm{~h}$.

\footnotetext{
* The concentration of papain to be used will be determined by its potency; the level necessary to give maximal responses is required. In the Panel's work this was achieved with $2 \mathrm{ml}$ of a $4 \%$ solution of crude papain (BDH). This sample had a potency of I'3 Anson units/g (Anson, 1938-9). Methionine contributed by the papain should be corrected for by an appropriate blank determination.
} 
Measurement of growth response. After incubation heat the tubes in flowing steam for Io min and cool them to room temperature. Stopper the tubes and shake them vigorously; set them aside for $2-3$ min to allow air bubbles to rise and food particles to settle. Read the optical densities of the cultures with a suitable photoelectric instrument or measure the titratable acidities.

Calculation of results. Plot a curve of the average responses to the standard and read off the indicated potency of the test sample at at least three concordant levels. If the potencies estimated from the various levels differ by more than $\pm 15 \%$ from their mean the assay is invalid and must be discarded.

Report the mean potency estimate as available methionine per $16 \mathrm{~g} \mathrm{~N}$ in the sample.

\section{APPENDIX B}

Assay of available lysine and methionine with Tetrahymena pyriformis $W$

The general assay technique was that of Stott $e$ al. $(1963)$ for the nutritive value of proteins. The exact procedure for assay of available amino acids in studies I, 2 and 3 is given in Appendix Table 2 (see also Stott \& Smith, 1966 ).

Amino acid solution $F$. The composition of the amino acid solution, based on the $2 \mathrm{C}$ medium of Kidder \& Dewey (195I) is given below. Omit the amino acid to be measured from the solution.

Amino acid standard response curves. The levels per ro $\mathrm{ml}$ of assay medium (i.e. per assay bottle) for the subject essential amino acids are: (a) L-lysine hydrochloride, $0-3.5 \mathrm{mg}$ in $0.25 \mathrm{mg}$ increments; $(b) \mathrm{L}$-methionine, $0-0.8 \mathrm{mg}$ in $0.1 \mathrm{mg}$ increments. Prepare solutions containing the highest amino acid level $/ \mathrm{ml}$ and dilute them to give the appropriate lower levels.

Solution G. Make up ro $\mathrm{ml}$ of $30 \%$ glucose, $2 \mathrm{ml}$ solution A (p. 205) and $80 \mathrm{ml}$ solution $\mathrm{F}$ to $100 \mathrm{ml}$ with distilled water to give solution $\mathrm{G}$, which is twice as strong as the required final medium.

Test material suspensions. Prepare suspensions to contain $5 \mathrm{mg} \mathrm{N} / 3 \mathrm{ml}$ and three other dilutions from this suspension to give 2, 3 and $4 \mathrm{mg} \mathrm{N} / 3 \mathrm{ml}$. Adjust test material suspensions to $\mathrm{pH} 8 \cdot 2$. Assay samples in duplicate at each of the four $\mathrm{N}$ levels.

Assay medium. This consists of: (a) $2 \mathrm{ml}$ of solution $\mathrm{E} ;(b) 3 \mathrm{ml}$ of $3 \frac{1}{3}$ times strength test-material suspension or $\mathrm{I} \mathrm{ml}$ of ten times strength standard solution of the amino acid to be estimated plus $2 \mathrm{ml}$ distilled water. After sterilizing the above solutions in $2 \mathrm{oz}$ screw-capped 'medical flat' assay bottles at $12 \mathrm{I}^{\circ}$ for $\mathrm{Io}$ min, add aseptically $5 \mathrm{ml}$ of sterile solution $\mathrm{G}$ to each bottle.

Incubation. Inoculate each bottle with three drops of a 3 -day broth culture of $T$. pyriformis $\mathrm{W}$ and incubate at $25^{\circ}$ for 4 days. Leave the screw caps loose during this period and incline the bottles in racks at $15^{\circ}$ to the horizontal to provide sufficient aeration for rapid growth.

Measurement of growth response. After 4 days' incubation, transfer $\mathrm{I} \mathrm{ml}$ of the culture medium to a $\frac{1}{4} \mathrm{oz}$ screw-capped bottle containing $\mathrm{I} \mathrm{ml}$ preserving fluid (consisting of $90 \mathrm{ml}$ water, $20 \mathrm{ml} 36 \%(\mathrm{w} / \mathrm{v})$ formaldehyde and $10 \mathrm{ml}$ of stock solution D (p. 205)). Count the organisms in eight $1 \mathrm{~mm}$ squares of a haemocytometer, depth $0.2 \mathrm{~mm}$, 
Table 2. Composition of stock solution for the Tetrahymena pyriformis $W$ assay of available lysine or available methionine content

\begin{tabular}{|c|c|}
\hline Stock solution A (roo times final strength) & $\mathrm{mg} / 200 \mathrm{ml}$ \\
\hline Calcium pantothenate & $12 \cdot 5$ \\
\hline Nicotinamide & $12 \cdot 5$ \\
\hline Pyridoxine hydrochloride & $125^{\circ} 0$ \\
\hline Pyridoxal hydrochloride & $12 \cdot 5$ \\
\hline Pyridoxamine hydrochloride & $12 \cdot 5$ \\
\hline Riboflavine & $12 \cdot 5$ \\
\hline Folic acid & $\mathrm{I} \cdot 25$ \\
\hline Thiamine hydrochloride & $125 \cdot 0^{\circ}$ \\
\hline Inositol & $12 \cdot 5$ \\
\hline Choline chloride & $125^{\circ} 0$ \\
\hline$p$-Aminobenzoic acid & $12 \cdot 5$ \\
\hline Biotin & $I \cdot 25$ \\
\hline DL- $\alpha$-Lipoic acid & 0.4 \\
\hline $\begin{array}{l}\text { Stock solution } \mathrm{B} \text { (100 times final strength) } \\
\mathrm{MgSO}_{4} \cdot 7 \mathrm{H}_{2} \mathrm{O} \\
\mathrm{Fe}\left(\mathrm{NH}_{4}\right)_{2}\left(\mathrm{SO}_{4}\right)_{2} \cdot 6 \mathrm{H}_{2} \mathrm{O} \\
\mathrm{MnCl}_{2} \cdot 4 \mathrm{H}_{2} \mathrm{O} \\
\mathrm{ZnCl}_{2}\end{array}$ & $\begin{array}{l}\mathrm{g} / 200 \mathrm{ml} \\
2 \cdot 8 \\
\mathrm{I} \cdot 25 \\
0.025 \\
0.0025\end{array}$ \\
\hline $\begin{array}{l}\text { Stock solution } \mathrm{C} \text { (100 times final strength) } \\
\mathrm{CaCl}_{2} \cdot 2 \mathrm{H}_{2} \mathrm{O} \\
\mathrm{CuCl}_{2} \cdot 2 \mathrm{HO} \\
\mathrm{FeCl}_{3} \cdot 6 \mathrm{H}_{2} \mathrm{O}\end{array}$ & $\begin{array}{l}\mathrm{mg} / 200 \mathrm{ml} \\
600 \\
60 \\
15\end{array}$ \\
\hline $\begin{array}{l}\text { Stock solution } \mathrm{D} \text { (100 times final strength) } \\
\mathrm{KH}_{2} \mathrm{PO}_{4} \\
\mathrm{~K}_{2} \mathrm{HPO}_{4}\end{array}$ & $\begin{array}{c}\mathrm{g} / 200 \mathrm{ml} \\
3 \cdot 5 \\
3 \cdot 5\end{array}$ \\
\hline
\end{tabular}

Solution E ( 5 times single strength)

The appropriate weights of the components listed below are dissolved in approximately ro $\mathrm{ml}$ distilled water, $1 \mathrm{ml}$ stock solutions $\mathrm{B}, \mathrm{C}, \mathrm{D}$ added and the whole made up to 20 $\mathrm{ml}$, adjusting the $\mathrm{pH}$ to $7^{\cdot 1}$ with $\mathrm{NaOH}$.

Guanylic acid (sodium salt)

Adenosine-2' $2^{\prime}\left(3^{\prime}\right)$-phosphoric acid monohydrate

Cytidylic acid

Uracil

\section{$\mathrm{mg} / 20 \mathrm{ml}$ solution $\mathrm{E}$}

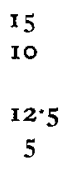

Solution F ( $2 \frac{1}{2}$ times final strength)

\begin{tabular}{|c|c|c|c|}
\hline \multicolumn{3}{|c|}{$\mathrm{mg} / 100 \mathrm{ml}$} & $\mathrm{mg} / 100 \mathrm{ml}$ \\
\hline DL-Alanine & $97 \cdot 8$ & L-Proline & $156 \cdot 4$ \\
\hline L-Arginine hydrochloride & 93.0 & L-Leucine & $173^{\circ} \circ$ \\
\hline L-Aspartic acid & $108 \cdot 7$ & L-Cystine* & 20.0 \\
\hline Glycine & $8 \cdot 9$ & DL-Serine & 137.4 \\
\hline L-Glutamic acid & $207 \cdot 2$ & L-Threonine & $78 \cdot 4$ \\
\hline L-Histidine hydrochloride & $46 \cdot 2$ & L-Tryptophan & $2 r \cdot 3$ \\
\hline L-Isoleucine & $56 \cdot 0$ & DL-Valine & $1 \times 7 \cdot 6$ \\
\hline L-Phenylalanine & $89 \cdot 0$ & L-Lysine hydrochloride $\dagger$ & 167.2 \\
\hline L-Methionine† & $30 \cdot 3$ & & \\
\hline
\end{tabular}

* Dissolve separately in $\mathrm{NaOH}$ solution before addition to the remainder.

$\dagger$ Omit lysine or methionine as necessary.

Solution $\mathrm{G}$

ro $\mathrm{ml} 30 \%$ glucose solution $+2 \mathrm{ml}$ solution $\mathrm{A}+80 \mathrm{ml}$ solution $\mathrm{F}$ (omitting L-lysine hydrochloride or $\mathrm{L}$-methionine) to $100 \mathrm{ml}$ at $\mathrm{pH} 7 \cdot \mathrm{I}$, adjusting $\mathrm{pH}$ with $\mathrm{NaOH}$. 
Fuchs-Rosenthal rulings to BS 748. The mean number per I $\mathrm{mm}$ square gives the final population of the test culture in units of $10^{4}$ organisms $/ \mathrm{ml}$.

Calculation of available amino acid content. Read off values for the test materials from the response curve for the pure amino acid standard. Average the figures for the four nitrogen levels used, omitting values that differ by more than $20 \%$ from the mean.

\section{REFERENCES}

Anantharaman, K. \& Carpenter, K. J. (1965). Proc. Nutr. Soc. 24, xxxii.

Anson, M. L. (1938-9). F. gen Physiol. 22, 79.

Barber, R. S., Braude, R., Chamberlain, A. G., Hosking, Z. D. \& Mitchell, K. G. (1964). Br. F. Nutr. $\mathbf{r} 8,545$.

Barton-Wright, E. C. (1963). Practical Methods for the Microbiological Assay of the Vitamin B Complex and Amino Acids. London: United Trade Press Ltd.

Baum, F. \& Haenel, H. (1965). Nahrung 9, 517.

Boyne, A. W., Carpenter, K. J. \& Woodham, A. A. (1961). F. Sci. Fd Agric. 12, 832.

Bunyan, J. \& Price, S. A. (r960). F. Sci. Fd Agric. 11, 25.

Bunyan, J. \& Woodham, A. A. (1964). Br. F. Nutr. 18, 537.

Carpenter, K. J. (1960). Biochem. $\mathscr{F} .77,604$.

Carter, D. V. \& Sykes, G. (1961). F. Pharm. Pharmac. 13, r95 T.

Celliers, P. G. (1961). S. Afr. F. agric. Sci. 4, 191.

Dunn, M. S. \& Rockland, L. B. (1947). Proc. Soc. exp. Biol. Med. 64, 377.

Fernell, W. R. \& Rosen, G. D. (1954). Proc. Nutr. Soc. 13, xviii.

Fernell, W. R. \& Rosen, G. D. (1956). Br. F. Nutr. ro, 143.

Ford, J. E. (I960). Br. F. Nutr. I4, 485 .

Ford, J, E. (1962). Br. \%. Nutr. I6, 409.

Ford, J. E. (1964). Br. F. Nutr. 18, 449 .

Halevy, S. \& Grossowicz, N. (1953). Proc. Soc. exp. Biol. Med. 82, 567.

Horn, M. J., Blum, A. E. \& Womack, M. (1954). F. Nutr. 52, 375.

Kidder, G. W. \& Dewey, V. C. (r95 I). In Biochemistry and Physiology of Protozoa. Vol. I, p. 323. [A. Lwoff, editor.] New York: Academic Press Inc.

Mertz, E. T., Rennert, S. S. \& Cole, E. W. (1955). F. Nutr. 56, 437.

Miller, E. L., Carpenter, K. J. \& Milner, C. K. (1965). Br. $\mathcal{F}$. Nutr. I9, 547.

Miller, E. L., Carpenter, K. J. \& Morgan, C. B. (1963). Proc. int. Congr. Nutr. vi. Edinburgh p. 488.

Miller, E. L., Carpenter, K. J., Morgan, C. B. \& Boyne, A. W. (r965). Br. F. Nutr. r9, 249.

Pilcher, H. L. \& Williams, H. H. (I954). F. Nutr. 53, 589.

Rao, M. N., Sreenivas, H., Swaminathan, M., Carpenter, K. J. \& Morgan, C. B. (I963). F. Sci. Fd Agric. 14, 544.

Rockland, L. B. \& Dunn, M. S. (1946). Archs Biochem. II, 541.

Rogers, C. G. \& McLaughlan, J. M. (1958). Bact. Proc. p. 20.

Rogers, C. G., McLaughlan, J. M. \& Chapman, D. G. (1959). Can. F. Biochem. Physiol. 37, 1351.

Rosen, G. D. (1959). Proc. int. Symp. Microchem., 1958, p. 212 . London: Pergamon Press.

Rosen, G. D. \& Fernell, W. R. (1954). Proc. Nutr. Soc. I3, xix.

Rosen, G. D. \& Fernell, W. R. (1956). Br. $尹$. Nutr. ro, 1 56.

Rosen, G. D., Stott, J. A. \& Smith, H. (1960a). Proc. int. Congr. Nutr. v. Washington p. 72.

Rosen, G. D., Stott, J. A. \& Smith, H. (1960b). Proceedings of the Pfizer European Agricultural Research Conference, p. 368. [J. Vernon and G. D. Rosen, editors]. Tonbridge, Kent: Tonbridge Printers Ltd.

Rosen, G. D., Stott, J. A. \& Smith, H. (r962). Cereal Sci. Today. 7, 36.

Saunders, J. \& McFadyen, M. H. (1964). Nature, Lond. 202, 594.

Shockman, G. D. (1963). Analytical Microbiology, p. 567. [F. Kavanagh, editor.] New York: Academic Press Inc.

Stott, J. A. \& Smith, H. (1966). Br. F. Nutr. 20, 663.

Stott, J. A., Smith, H. \& Rosen, G. D. (I963). Br. F. Nutr. r7, 227.

Teeri, A. E., Virchow, W. \&: Loughlin, M. E. (1956). F. Nutr. 59, 587.

Teunisson, D. J. (196r). Analyt. Biochem. 2, 405.

Waterworth, D. G. (1964). Br. F. Nutr. 18, 503.

Zuckerman, S. (1959). Nature, Lond. 183, I 303. 